\title{
Medical Treatment Can Unintentionally Alter the Regulatory T-Cell Compartment in Patients with Widespread Pathophysiologic Conditions
}

\author{
Sabrina N. Copsel, Thomas R. Malek, and Robert B. Levy
}

From the Department of Microbiology and Immunology, University of Miami Miller School of Medicine, Miami, Florida

Accepted for publication

July 20, 2020.

Address correspondence to Sabrina N. Copsel, Ph.D., Department of Microbiology and Immunology, University of Miami Miller School of Medicine, 1600 N.W. 10th Ave., RMSB \#3014, Miami, FL 33136. E-mail: snc49@ med.miami.edu.

\begin{abstract}
Regulatory T cells (Tregs) are non-redundant mediators of immune tolerance that are critical to prevent autoimmune disease and promote an anti-inflammatory tissue environment. Many individuals experience chronic diseases and physiologic changes associated with aging requiring long-term medication. Unfortunately, adverse effects accompany every pharmacologic intervention and may affect overall outcomes. We focus on medications typically prescribed during the treatment of prevalent chronic diseases and disorders, including cardiovascular disease, autoimmune disease, and menopausal symptoms, that affect $>200$ million individuals in the United States. Increasing studies continue to report that treatment of patients with estrogen, metformin, statins, vitamin $D$, and tumor necrosis factor blockers are unintentionally modulating the Treg compartment. Effects of these medications likely comprise direct and/or indirect interaction with Tregs via other immune and parenchymal populations. Differing and sometimes opposing effects on the Treg compartment have been observed using the same medication. The length of treatment, dosing regimen and stage of disease, patient age, ethnicity, and sex may account for such findings and determine the specific signaling pathways affected by the medication. Enhancing the Treg compartment can skew the patient's immune system toward an anti-inflammatory phenotype and therefore could provide unanticipated benefit. Currently, multiple medicines prescribed to large numbers of patients influence the Treg compartment; however, how such effects affect their disease outcome and long-term health remains unclear. (Am J Pathol 2020, 190: 2000-2012; https://doi.org/10.1016/j.ajpath.2020.07.012)
\end{abstract}

Currently, a number of medications, including estrogen, metformin, statins, vitamin $\mathrm{D}$, and tumor necrosis factor (TNF) inhibitors, are being prescribed to millions of individuals for extended periods because they provide clinical benefits and improve quality of life. According to the Centers for Disease Control and Prevention, "Chronic diseases are defined broadly as conditions that last one year or more and require ongoing medical attention or limit activities of daily living or both. Chronic diseases including heart disease, cancer, and diabetes are the leading causes of death and disability in the United States" (CDC, www.cdc.gov/ chronicdisease/about/index.htm, last accessed May 27, 2020). Such diseases are also major drivers of the nation's approximately $\$ 3.5$ trillion expenditures in annual health care costs. Modifiable behaviors, such as poor nutrition (including diets low in fruits and vegetables and high in sodium and saturated fats), minimal or absent physical activity, excessive alcohol consumption, and tobacco use, contribute to many chronic diseases and conditions, including cardiovascular disease, diabetes, and vitamin D deficiency (CDC, www.cdc.gov/chronicdisease/about/ index.htm, last accessed May 27, 2020).

Regulatory $\mathrm{T}$ cells (Tregs) are a unique subset of lymphoid cells responsible for controlling responses by the

Supported by Sylvester Comprehensive Cancer Center grant PG005185 (S.N.C., R.B.L.); NIH grants R01AI148675 (T.R.M.), R01AI131648 (T.R.M.), R01 EY024484 (R.B.L.), R01 EY030283 (R.B.L.), and R41 AI149916 (R.B.L.); and Heat Biologics/Pelican Therapeutics SRA GR010438 (S.R.A.).

Disclosures: None declared. 
adaptive immune system and maintaining immunologic selftolerance. In the human immune system, these cells are defined by a consensus phenotype, including expression of $\mathrm{CD} 4, \mathrm{CD} 25$, and $\mathrm{CD} 127^{\mathrm{lo}}$ on the cell surface together with expression of the nuclear transcription factor $\mathrm{FOXP}^{+}-$the hallmark of mouse Treg cells. ${ }^{1,2}$ The cytokine IL-2 is essential for the survival and proliferation of this T-cell subset because the absence of IL-2 receptor signaling results in a loss of Tregs and onset of autoimmune symptoms. ${ }^{3}$ Experimental studies in mice found that the absence of this population after knockout of the FOXP3 gene resulted in rapid onset in $100 \%$ of animals of autoimmune pathology. ${ }^{4}$ Such findings correlate with the clinical disorder immunodysregulation polyendocrinopathy enteropathy $\mathrm{X}$-linked, which occurs in individuals with mutated FOXP3 genes. ${ }^{5}$ Notably, a change in numbers and/or function have been reported in several autoimmune and inflammatory disorders, including type 1 diabetes (T1D), multiple sclerosis (MS), rheumatoid arthritis (RA), inflammatory bowel disease (IBD), and graft-versus-host disease (GVHD). ${ }^{6,7}$ Accordingly, experimental studies and clinical trials are under way, involving cell therapy and in vivo manipulation of Tregs in attempts to ameliorate these diseases. Early studies have provided promising results in T1D and GVHD, encouraging continued research to better understand. ${ }^{8,9}$

Within the past decade, there has been significant expansion in development and implementation of pharmaceutical compounds to treat patients, which is advancing the ability of the medical community to ameliorate disease. As more effective compounds have been identified together with increasing medical knowledge, more successful treatment of many conditions has occurred; hence, patients with chronic disease are living longer. One consequence of this increased lifespan is that individuals will be prescribed many medications and therefore become exposed to multiple drugs for extended periods. Unfortunately, unintended and often adverse effects accompany virtually every pharmacologic intervention and may have a great effect on overall outcomes. In this context, one study in 2013 reported that $>600$ US Food and Drug Administration (FDA)-approved compounds used for treating inflammation, hypertension, heart disease, and infections were systematically evaluated and approximately 180 increased Treg counts. ${ }^{10}$ This review focuses on a number of medications typically prescribed during the treatment of prevalent chronic diseases and physiologic conditions that affect $>200$ million persons in the United States. Estrogen, metformin, statins, vitamin D, and TNF inhibitors (Table $1^{11-32}$ ) were selectively chosen because i) they are widely used, ii) each is administered for an extended period, and iii) there are data in the literature documenting their unintentional effect on the Treg compartment. Notably, these medications are not being prescribed with the intent to ameliorate the condition via manipulation of the patient's Treg compartment. Other drugs that do not meet these criteria, such as cytotoxic and chemotherapeutic agents, will not be discussed in this review.

\section{Estrogen and Progesterone}

In addition to their role as natural hormones, estrogens are used as medications, for example, in menopausal hormone therapy (MHT) and hormonal birth control. ${ }^{11}$ Estrogen therapy has been used alone or in combination with progesterone as the most effective treatment for menopausal symptoms, including night sweats, hot flashes, and vasomotor symptoms. MHT with estrogen also may have positive effects on preventing osteoporosis or cardiovascular disease, particularly for women with early-onset primary ovarian insufficiency. Importantly, the MHT for women with cardiovascular or breast cancer risks varies, depending on risk and benefit considerations. ${ }^{11}$ Regarding birth control, two types of medications available: pills that contain estrogen and progestin and progestin-only pills. Overall, the estimate of the number of women in the United States using MHT and hormonal birth control is approximately 15 million (CDC, https://www.cdc.gov/hchs/ products/databriefs/db327.htm, last accessed May 29, 2020; National Heart, Lung, and Blood Institute, https://www. nhlbi.nih.gov/files/docs/pht_facts.pdf, last accessed May 29, 2020).

As well as regulating reproductive functions, estrogen can also affect the development and activation of immune responses and together can modify bone metabolism. ${ }^{33,34}$ In the context of the present review, it is well established that this hormone can alter the Treg compartment. Under physiologic conditions during the menstrual cycle of fertile nonpregnant women, an increase of $\mathrm{CD} 4{ }^{+} \mathrm{CD} 25^{+} \mathrm{FOXP} 3^{+}$ Treg levels in peripheral blood was observed in the late follicular phase. This expansion was associated with high serum levels of estradiol and was followed by a significant diminution of Tregs in the luteal phase. ${ }^{12}$ In contrast, in women with recurrent spontaneous abortions or after menopause, lower Treg counts and decreases in their suppressive function were detected at both the follicular and the luteal phases compared with fertile women. ${ }^{12}$ In postmenopausal women, the occurrence of osteoporosis has been associated with estrogen deficiency, which leads to osteoclast-mediated bone resorption. ${ }^{35}$ The protective role of estrogen in bone metabolism has been proposed to be by regulating Treg function on osteoclast differentiation and bone resorption. Supporting this hypothesis, ex vivo treatment of human Tregs with physiologic levels of estradiol resulted in an increase in Treg frequency, activation, and secretion of IL-10 and transforming growth factor (TGF)$\beta .^{36,37}$ This latter effect also promoted an increase in Tregmediated suppressive effects on osteoclast differentiation, preventing greater bone resorption. ${ }^{37}$

The molecular mechanism by which estrogen expands Tregs was studied in primary human Tregs from peripheral blood of healthy males and cervical cancers from patients. ${ }^{13}$ Inhibition of estrogen receptor (ER) $\alpha$ with a specific antagonist impaired the tumor-infiltrating Tregs by blocking FOXP3 expression, thereby inhibiting their function. Using co-immunoprecipitation, the authors found that estradiol 
Table 1 Summary of Medications Discussed in This Review Article That Can Affect the Treg Compartment in Patients

\begin{tabular}{|c|c|c|c|c|c|}
\hline Medication & Disease or condition & Mechanism of action & Major biological effect & $\begin{array}{l}\text { Changes in Treg } \\
\text { compartment }\end{array}$ & References \\
\hline Estrogen & $\begin{array}{l}\text { Menopause, premature } \\
\text { ovarian failure, or birth } \\
\text { control }\end{array}$ & Targeting ERs (ER $\alpha / E R \beta)$ & $\begin{array}{l}\text { Reduces menopausal } \\
\text { symptoms (eg, night } \\
\text { sweats and hot flashes). } \\
\text { regulate menstrual cycle }\end{array}$ & $\begin{array}{l}\text { Frequency, numbers, } \\
\text { phenotype, and } \\
\text { function }\end{array}$ & $11-13$ \\
\hline Metformin & Type 2 diabetes & $\begin{array}{l}\text { Inhibits mitochondrial } \\
\text { respiratory chain } \\
\text { complex I and activates } \\
\text { AMPK }\end{array}$ & $\begin{array}{l}\text { Decreases hepatic glucose } \\
\text { production, lowering } \\
\text { blood glucose levels }\end{array}$ & Frequency and numbers & $14-17$ \\
\hline Statins & $\begin{array}{l}\text { Cardiovascular disease, } \\
\text { dyslipidemia }\end{array}$ & $\begin{array}{l}\text { Inhibits HMG-CoA } \\
\text { reductase }\end{array}$ & Reduces cholesterol & $\begin{array}{l}\text { Frequency, numbers, } \\
\text { migration, phenotype, } \\
\text { and function }\end{array}$ & $18-21$ \\
\hline Vitamin D & $\begin{array}{l}\text { Bone disease } \\
\text { (osteoporosis, } \\
\text { osteomalacia, skeletal } \\
\text { fractures) }\end{array}$ & Targets vitamin $\mathrm{D}$ receptor & $\begin{array}{l}\text { Regulates calcium, } \\
\text { phosphorus, and bone } \\
\text { metabolism }\end{array}$ & $\begin{array}{l}\text { Frequency, migration, } \\
\text { phenotype, and } \\
\text { function }\end{array}$ & $22-27$ \\
\hline
\end{tabular}

AMPK, AMP-activated protein kinase; ER, estrogen receptor; TNF, tumor necrosis factor; Treg, regulatory T cell.

drives FOXP3 expression and promotes function in the cancer-derived Tregs by direct interaction between the estradiol:ER $\alpha$ complexes with the FOXP3 promotor. $^{13}$ Furthermore, chromatin immunoprecipitation analyses of male blood Tregs revealed that ER $\alpha$ binds to four different sites along the FOXP3 locus, including regions upstream and within the core of the promotor and conserved noncoding DNA elements 2 and 3. Computational analyses of enriched regions found eight putative estrogen response elements and predicted the forming of a loop that can trigger the FOXP3 promotor $^{13,38}$ (Figure 1).

Preclinical studies in estradiol-treated and pregnant mice have also found that estrogen drives Treg expansion and enhances their suppressive function by signaling through $\mathrm{ER} \alpha{ }^{39}$ Of note, $\mathrm{CD} 4^{+} \mathrm{T}$ cells express significantly higher levels of ER $\alpha$ compared with ER $\beta .^{40}$ Estradiol treatment protected mice from experimental autoimmune encephalitis, a mouse model of human MS, by increasing Foxp3 expression within the CD4 compartment. ${ }^{39}$ Furthermore, treatment with this hormone increased the intracellular levels of checkpoint inhibitor programed death (PD)-1 in FOXP3 ${ }^{+}$Tregs ${ }^{41}$ which may contribute to their functionality. Accordingly, in ER knockout mice, PD-1 expression and Treg suppressive function were diminished. ${ }^{41}$ Moreover, failure of Treg function in patients with MS was attributed to further reduced expression of $\mathrm{ER} \beta$, which might contribute to the pathogenesis of this disease. ${ }^{42}$ Most studies reported that estrogen alleviates the symptoms of autoimmune and inflammatory diseases. However, in IBD the role of estrogen and ER is unclear. In a mouse model of IBD, ER $\alpha$ deficiency in T cells reduced the pathologic findings by lowering Th1 and Th17 responses and favoring Foxp3 expression and consequently induced Treg (iTreg) differentiation. ${ }^{43}$ In humans, oral contraceptive use was associated with the development of $\mathrm{IBD}^{44}$ although in a more current study, MHT protected women from IBD. ${ }^{45}$ These findings indicate that in patients with IBD, estrogen can mediate immunostimulatory or immunosuppressive effects, depending on cell type examined and context of disease. Therefore, the significance of estrogen regarding Tregs in IBD remains to be determined.

Progesterone effects on Tregs have been less studied. For instance, this hormone promoted in vitro differentiation of naive cord blood fetal $\mathrm{T}$ cells, but not peripheral blood adult $\mathrm{T}$ cells, into iTregs. Mechanistically, progesterone increased IL2/STAT5 signaling while repressing IL-6-mediated STAT3 activation, facilitating T-cell differentiation into Tregs over Th17 cells. ${ }^{46}$ Preclinical studies revealed that progesterone expanded systemic and local uterine $\mathrm{CD} 4{ }^{+} \mathrm{CD} 25^{+}$Tregs and enhanced their suppressive activity during midterm pregnancy in mice. ${ }^{47}$ Although fewer data have been reported, androgens significantly augment Treg levels both in vivo and in vitro. A functional androgen response element was identified within the FOXP3 locus, and an androgen-dependent increase of FOXP3 expression was found in human $\mathrm{T}$ cells from women but not from men, indicating sex-specific androgen signaling. ${ }^{48}$

In total, estrogen and, to a more limited extent, progesterone appear to be drivers of Tregs, indicating that woman receiving MHT and taking birth control medications are likely to experience long-term changes in this lymphoid subset. Nonetheless, it is currently unknown whether these changes will result in a decrease in autoimmune disease or other clinical effects.

\section{Metformin}

Type 2 diabetes (T2D) is characterized by insulin resistance, which impairs cellular uptake of glucose and is accompanied 


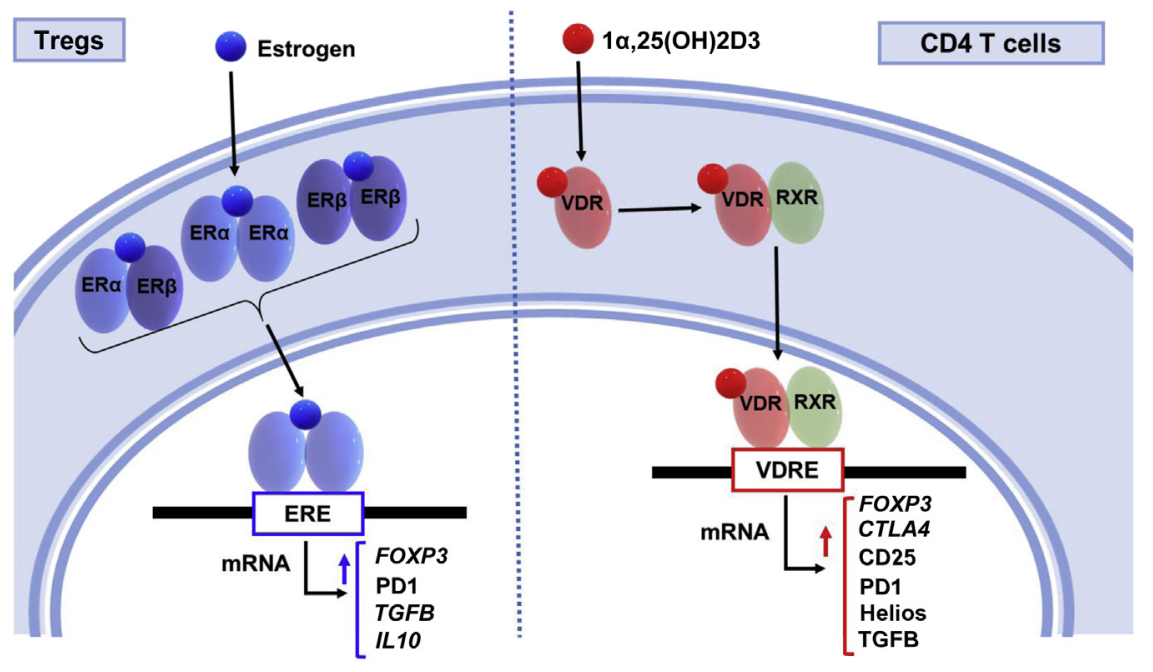

Figure 1 Schematic model for estrogen receptor (ER) and vitamin D receptor (VDR) signaling in regulatory $T$ cells (Tregs) and CD4 T cells. Estrogen (left panel) binds to the intracellular ER, which dimerizes (homo/heterodimers), undergoes translocation to the nucleus, and then interacts with estrogen response elements (EREs), inducing the expression of several genes, including FOXP3, PD1 (PDCD1), IL10, and TGFB. 1 $\alpha, 25$-dihydroxyvitamin $D_{3}\left[1 \alpha, 25(0 \mathrm{H})_{2} D_{3}\right]$ (right panel) binds to the VDR, interacts with the retinoid $X$ receptor (RXR), forming a heterodimer that engages vitamin $D$ responsive elements (VDREs) and upregulating the expression of FOXP3, CTLA4, CD25 (IL2RA), Helios (IKZF2), and other genes. by hyperglycemia. Chronic hyperglycemia leads to damage of blood vessels that ultimately can affect multiple organs, leading to serious health consequences. According to the CDC, approximately 30 million individuals in the United States have T2D, in part related to the obesity epidemic, making T2D one of the most common diseases that primarily affects older individuals.

Persistent, low-grade, obesity-induced inflammation is thought to be a major mechanism that contributes to insulin resistance and T2D. ${ }^{49}$ The accumulation of fat enhances a chemotactic gradient to attract monocytes and lymphocytes. Key proinflammatory cells that dominate adipose tissue from obese individuals include macrophages, Th1 and Th17 $\mathrm{CD}^{+} \mathrm{T}$ cells, $\mathrm{CD} 8^{+}$cytotoxic lymphocytes, and natural killer cells. These cells produce TNF- $\alpha$, IL-6, C-reactive protein, interferon (IFN)- $\gamma$, and IL-17, among other cytokines, to contribute to adipose tissue inflammation. Brown adipose tissue in lean mice contains a high proportion of a specialized subset of Tregs that depends on peroxisome proliferator-activated receptor- $\gamma$ for their development and proliferate to adipose-derived IL-33. ${ }^{50,51}$ These immunosuppressive Tregs dominate the $\mathrm{CD} 4^{+} \mathrm{T}$-cell compartment in lean mice, whereas they are at lower proportions in fat from obese mice. Indeed, fat in lean mice might have a higher ratio of Tregs:Th1 cells, and immunotherapy that increases Tregs in the fat limits insulin resistance and metabolic disorders in a mouse model of T2D. ${ }^{52,53}$ Collectively, these data suggest that Tregs within visceral fat are beneficial to limit inflammatory responses that promote insulin resistance and T2D.

Metformin is an extensively used drug in patients with T2D and exhibits pleotropic effects that help to lower blood glucose levels. ${ }^{14}$ Metformin is readily taken up by hepatocytes through Oct1 to concentrate it in the mitochondria to inhibit complex I of the respiratory chain, which lowers ATP production and increases the ratio of ADP:ATP and AMP:ATP. These changes act to activate AMP-activated protein kinase (AMPK), and all act in concert to antagonize other mitochondrial-associated enzymes to lower production of glucose and lipids, while increasing insulin sensitivity of the hepatocytes. A relatively high concentration of metformin is found in the intestine and acts to increase glucose metabolism and thus lowers glucose uptake. This drug also supports a shift in the somewhat distinctive gastrointestinal microbiome in T2D toward a microbiome more commonly associated with healthy individuals. In addition, metformin increases glucose uptake and insulin sensitivity in muscle cells.

In limited studies, the peripheral blood mononuclear cells of patients with T2D produced a modest decrease in Tregs, with somewhat lower suppressive activity. ${ }^{54}$ Human visceral adipose tissue in morbid obesity and lean adipose tissue from healthy individuals had low numbers of Tregs. ${ }^{55}$ Another important issue, therefore, is the extent that metformin affects Tregs because these cells are generally important to maintain self-tolerance and, more specifically, have been implicated in limiting inflammation associated with T2D, as discussed above. In vitro studies found that metformin inhibits proliferation of purified $\mathrm{T}$ lymphocytes in part by affecting $\mathrm{T}$-cell receptor signaling, suggesting a potential to inhibit T-effector cells. ${ }^{56,57}$ In mouse models of experimental autoimmune arthritis, IBD, experimental autoimmune encephalomyelitis, and systemic lupus erythematous, metformin lowers the instances of autoimmunity by decreasing Th17 cells while increasing Tregs. ${ }^{15,58,59}$ Metformin acts to inhibit STAT3 while increasing AMPK, which in turn, inhibits the mammalian target of rapamycin (mTOR)-1 pathway; these molecular consequences help to explain the shift in the Th17:Treg balance to one that is more regulatory (Figure $2^{60,61}$ ). In IBD and experimental autoimmune encephalomyelitis, metformin is associated with decreased mRNA levels for TNF- $\alpha$ (TNF), IL-1 $\beta$ (IL1B), IL-6 (IL6), IL-8 (CXCL8), vascular endothelial growth factor (VEGFA), IL-17 


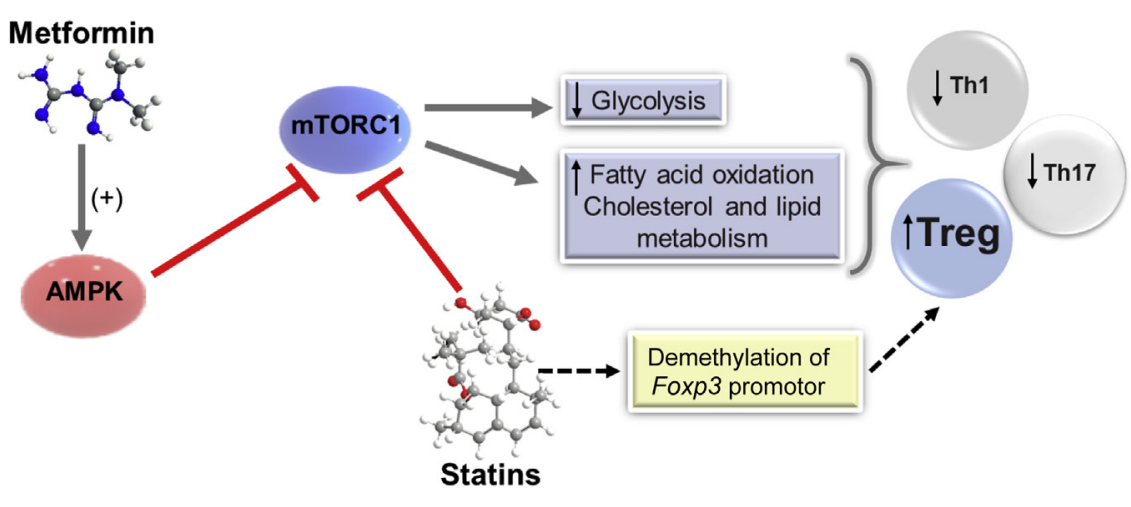

Figure 2 Metabolic reprogramming of T cells, leading to greater regulatory versus effector phenotype: schematic model for metformin and statin involvement. Regulation of the mammalian target of rapamycin (mTOR) complex 1 (mTORC1) pathway by AMP-activated protein kinase (AMPK) after metformin administration promotes fatty acid metabolism, which is the preferred energy pathway used by regulatory T cells (Tregs) but not naive or T effector cells. One study reported that human Treg cells from patients taking statins exhibited decreased phosphorylation of $\mathrm{mTOR}^{60}$ and a preclinical investigation noted that simvastatin demethylates the Foxp 3 promoter locus in mice. ${ }^{61} \mathrm{Th}$, T helper cells.
(IL17A), and retinoid-related orphan receptor $\gamma$ (RORC) but increased mRNA level for FOXP3 as well as increased Treg counts, ${ }^{15,59,62}$ consistent with lower inflammation. In the Roquin $^{\text {san/san }}$ mouse model of systemic lupus erythematous, these effects of metformin on STAT3, AMPK, and mTOR1 also inhibit autoantibody production by inhibiting the development of plasma cells. ${ }^{16}$ Metformin-dependent activation of AMPK inhibition of glycolysis and glutamine metabolism also favor metabolic reprograming of $\mathrm{T}$ lymphocytes to favor Tregs. ${ }^{17,63}$ For obese patients with MS, treatment with metformin leads to a significant reduction of the number of new brain lesions and is accompanied by increased Treg numbers in peripheral blood mononuclear cells. ${ }^{64}$ Collectively, these studies, which have been largely performed in mice, suggest that another favorable aspect of the use of metformin in patients with T2D is its ability to directly enhance immunosuppressive Tregs while limiting T-effector cells, particularly Th17 cells (Figure 2). Indeed, T cell-derived IL-17 is another inflammatory cytokine linked to obesity and T2D. ${ }^{65}$ On the basis of these findings, speculation is that metformin may limit obesity-associated inflammation in part through enhancing Treg levels. However, more direct evaluation of patients with T2D will be required to confirm this hypothesis.

\section{Statins}

Statins are widely used to reduce the risk of cardiovascular diseases and stroke, and it is estimated that approximately $30 \%$ of people $>40$ years of age and approximately 35 million people in the United States are taking a statin (https://www.drugs.com/ article/statins-benefits-and-risks.html, last accessed May 29, 2020). The benefit is a result of their capacity to inhibit the synthesis of cholesterol. This process occurs when statins block HMG-CoA reductase, a key regulatory enzyme of cholesterol biosynthesis. ${ }^{18}$ By inhibiting HMG-CoA reductase, statins diminish the hepatocyte cholesterol content together with an increase in LDL receptor expression, which results in increased clearance of LDL-C from the bloodstream and subsequent reduction in circulating LDL-C. In addition, statins have non-lipid-related pleiotropic activity, such as improving endothelial cell function, reducing risk of dementia, stabilizing atherosclerotic plaques, diminishing proliferation, and having anti-inflammatory, immunomodulatory, and antithrombotic properties. ${ }^{66}$ These cholesterol-independent effects of statins have been attributed to their capacity to inhibit the production of nonsteroidal isoprenoid compounds (eg, farnesyl-pyrophosphate and geranylgeranyl-pyrophosphate), which are intermediate metabolites in the cholesterol synthesis pathway. ${ }^{67,68}$

Although all statins reduce serum LDL in a dosedependent manner and share a common mechanism of action, they differ in their chemical structure, pharmacokinetic profiles, and efficacy. ${ }^{69}$ Currently, seven statins are on the market, including atorvastatin, fluvastatin, lovastatin, pravastatin, rosuvastatin, simvastatin, and pitavastatin and are used as single agents or as combination products. The most prevalent and well-documented adverse effect of statins is the development of muscle symptoms, which can present as myopathy, myalgia, myositis (with elevated creatinine kinase), and the most severe, fatal or nonfatal rhabdomyolysis. Other adverse effects include neurologic, hepatic, and renal toxic effects. In addition, statin treatment was associated with new-onset T2D, and this adverse effect appears to be more common in patients with preexisting risk factors (eg, increased body mass index, impaired fasting glucose, or elevated glycated hemoglobin level). ${ }^{70}$

Beyond the cholesterol-reducing effect, statins also have additional beneficial effects as a result of their regulation of the innate and adaptive immune systems. ${ }^{71}$ As immune modulating agents, statins reduce proinflammatory cytokines, inhibit antigen-presenting cell maturation and function, diminish the adhesion and activation of monocytes, and impair T-cell activation by inhibiting the induction of major histocompatibility complex 2 expression by IFN$\gamma^{72,73}$ Notably, among the CD4 ${ }^{+}$T-cell subsets, several studies have recently indicated that treatment with statins may increase Treg numbers, migration, differentiation, and/ or suppressive function. ${ }^{19}$ For, example, in one study, patients (38 to 75 years old) with acute coronary syndrome who were treated with low-dose atorvastatin $(20 \mathrm{mg} / \mathrm{d})$ for 4 weeks had an augmented frequency of Tregs in peripheral 
Table 2 FDA-Approved Medications That Target TNF- $\alpha$

\begin{tabular}{|c|c|c|c|}
\hline TNF- $\alpha$ inhibitor medications & Initial approval & Compound & $\overline{\text { Target }}$ \\
\hline Etanercept* (Enbrel) & 1998 for rheumatoid arthritis & Fusion protein: human TNFR2-IgG & $\mathrm{TNF}-\alpha$ \\
\hline Infliximab* (Remicade) & 1998 for Crohn disease & Chimeric mouse-human $\operatorname{IgG} 1 \kappa-\mathrm{mAb}$ & TNF- $\alpha$ \\
\hline Adalimumab* (Humira) & 2002 for rheumatoid arthritis & Human mAb & TNF- $\alpha$ \\
\hline Certolizumab (Cimzia) & 2008 for Crohn disease & PEGylated Fab fragment of a humanized mAb & TNF- $\alpha$ \\
\hline Golimumab (Simponi) & 2009 for rheumatoid arthritis & Fully human $\operatorname{IgG} 1 \kappa-\mathrm{mAb}$ & TNF- $\alpha$ \\
\hline
\end{tabular}

*Binds to soluble and transmembrane TNF- $\alpha .{ }^{112}$

Fab, antigen-binding fragment; FDA, US Food and Drug Administration; mAb, monoclonal antibody; PEG, polyethylene glycol; TNF, tumor necrosis factor; TNFR2, tumor necrosis factor receptor 2 .

blood (approximately two times), and functionally, their in vitro suppressive capacity was increased when compared with the same patient group before treatment. ${ }^{20}$ In a prospective randomized study, administration of a high dose of rosuvastatin before the procedure in patients with acute coronary syndrome receiving percutaneous coronary intervention also found increased Treg levels. ${ }^{74}$ Studies in Asia recently reported that acute coronary syndrome is characterized by increased effector cells and decreased Tregs and that statins increase the frequency of $\mathrm{CD} 4{ }^{+} \mathrm{CD} 25^{+} \mathrm{T}$ cells, although FOXP3 expression was not examined. ${ }^{75}$

In a setting of acute myocardial infarction, patients were evaluated and found that atorvastatin treatment $(80 \mathrm{mg})$ resulted in increased Treg frequency in peripheral blood and infarct-related coronary arteries accompanied by higher FOXP3 and TGF- $\beta$ (TGFB) mRNA levels compared with the control group. ${ }^{21}$ Moreover, in a retrospective study, patients with hypercholesterolemia treated with simvastatin $(20 \mathrm{mg})$ or pravastatin (10 to $40 \mathrm{mg}$ ) for 4 or 8 weeks, respectively, exhibited increased frequency of $\mathrm{CD} 4{ }^{+} \mathrm{CD} 25^{\text {high }}$ cells with upregulation of FOXP3 expression in the peripheral blood. ${ }^{76}$ It has been proposed that increased levels of Tregs in atherosclerotic lesions suppress Th1 and Th2 effector responses, reducing their contribution to the pathogenesis of atherosclerosis. ${ }^{77}$ Similar effects of statins on Treg phenotype and levels have been reported in several human ex vivo and mouse in vivol in vitro studies, supporting the notion that statins are positive regulators of this cell population. ${ }^{76,78}$ In addition to enhancing Treg levels, statins can also affect Treg cell migration. In a murine model of skin delayed-type hypersensitivity response to Candida albicans treated with lovastatin, upregulation of CCL1 occurred, and subsequent Treg recruitment to the inflamed tissues was detected. ${ }^{79}$ Dosage may be important because it was reported that higher concentrations of atorvastatin $(10 \mu \mathrm{M})$ inhibited Treg in vitro suppressive function and altered Treg phenotype by reducing the expression of Foxp3, the key regulatory molecule cytotoxic T-lymphocyte-associated protein (CTLA)-4, and PD- $1 .{ }^{80}$ Lastly, one study found that simvastatin treatment promoted generation of mouse Foxp3-expressing iTregs in vitro by inducing demethylation of the mouse Foxp 3 promotor and by releasing and potentiating the TGF- $\beta$ signaling pathway (Figure 2 ). ${ }^{61}$

In addition to statin treatment for cardiovascular diseases, the effect of these compounds on Treg populations has also been reported in patients with cancer and autoimmune disease as well as in healthy individuals. Briefly, in patients with colorectal cancer, atorvastatin treatment $(n=25 ; 10$, 20 , or $40 \mathrm{mg}$ ) led to an increase in $\mathrm{FOXP}^{+}$Treg infiltration with no differences in TGF- $\beta$ expression within tumor tissues. ${ }^{81}$ Patients with RA treated with atorvastatin $(20 \mathrm{mg} / \mathrm{d})$ for 12 weeks exhibited increased Treg counts and restored suppressive function. ${ }^{60}$ The molecular mechanism by which atorvastatin promotes the generation of human Tregs was attributed to the specific inhibition of phosphatidylinositol 3-kinase-Akt-mTOR and ERK signaling pathways (Figure 2) ${ }^{60}$ In healthy individuals (18 men without cholesterolemia), administration of lovastatin or atorvastatin for 45 days resulted in increased Treg frequency and FOXP3 mRNA levels by day 30 . However, at day 45, Treg counts returned to baseline, although FOXP3 and TGF- $\beta$ mRNA expression remained high. This inflammation-independent study found a positive correlation between Treg levels and HDL-C, suggesting a role of the latter in Treg homeostasis. ${ }^{82}$ In total, studies with statins have found that the Treg compartment in patients undergoes enhancement as assessed by multiple criteria. It appears that these changes are associated with reduced pathogenesis in cardiovascular and other diseases.

\section{Vitamin D}

The human daily requirement of vitamin $\mathrm{D}$ is obtained primarily from exposure to sunlight and from diet. Highenergy solar UVB photons penetrate the skin, causing the release of vitamin $D_{3}$, which undergoes two consecutive hydroxylations to become 1 $\alpha, 25$-dihydroxyvitamin $\mathrm{D}_{3}$ $\left[1 \alpha, 25(\mathrm{OH})_{2} \mathrm{D}_{3}\right]$, the active vitamin $\mathrm{D}$ metabolite. ${ }^{83}$ The first hydroxylation [ie, $25(\mathrm{OH}) \mathrm{D}_{3}$ ] occurs primarily in the liver and the second, to $1 \alpha, 25(\mathrm{OH})_{2} \mathrm{D}_{3}$, primarily in the kidney but also in immune cells. ${ }^{84}$ Vitamin $\mathrm{D}_{3}$ photoproduction is influenced by latitude of residence, season, and skin color. ${ }^{85}$ Vitamin $D_{3}$ is required to maintain skeletal and mineral homeostasis and thereby prevents bone disease. Hence, insufficient levels of this hormone exacerbate osteoporosis, augment the risk of skeletal fractures, and cause osteomalacia. ${ }^{22}$ Notably, vitamin D deficiency has also been associated with increased risks of a broad range of chronic 
inflammatory and autoimmune illnesses, including common cancers, cardiovascular disease, Crohn disease, T1D, MS, and RA. ${ }^{86,87}$ The most reliable marker of vitamin D status is the measure of $25(\mathrm{OH}) \mathrm{D}_{3}$ in serum, which is the main circulating metabolite of vitamin D. In recent years, several reports have proposed levels of vitamin $\mathrm{D}$ considered to be deficient, and accordingly, recommendations to supplement deficient states have been prescribed. ${ }^{87}$ It has been reported by the Endocrine Society in the United Kingdom and supported by the Institute of Medicine in the United States that individuals with $<20 \mathrm{ng} / \mathrm{mL}(50 \mathrm{nmol} / \mathrm{L})$ of $25(\mathrm{OH}) \mathrm{D}_{3}$ are identified as vitamin $\mathrm{D}$ deficient. ${ }^{87}$ However, controversy remains, and unanimity within the field is lacking regarding reference values defined by the Institute of Medicine. ${ }^{88}$ Readers should refer to several articles to further clarify the issues involved. ${ }^{88-90}$

$1 \alpha, 25(\mathrm{OH})_{2} \mathrm{D}_{3}$ exerts its functions by binding to the vitamin $\mathrm{D}$ receptor (VDR), triggering genomic and nogenomic responses that are mediated by nuclear VDR and caveolae-associated VDR of the plasma membrane, respectively. ${ }^{91}$ VDR is a DNA-binding transcription factor, and after binding to $1 \alpha, 25(\mathrm{OH})_{2} \mathrm{D}_{3}$, it interacts with the retinoid $\mathrm{X}$ receptor, forming an active signal transduction complex that binds to vitamin D response elements (VDREs), inducing the transactivation or repression of up to 500 primary target genes per tissue. $^{91,92}$ Through this process, vitamin D leads, in addition to established effects on mineral and bone metabolism, to upregulation of FOXP3, CTLA-4, Helios (IKZF2), suppression of IL-17, and consequently to Treg stimulation and Th1/Th17 suppression (Figure 1). ${ }^{23,91-94}$

The effects of vitamin D on the innate and adaptive immune system are mediated by the expression of the VDR in many immune cells, including $\mathrm{T}$ and $\mathrm{B}$ lymphocytes, macrophages, dendritic cells, and natural killer cells. ${ }^{24,95,96}$ The effects of VDR agonists on dendritic cells reduce the expression of costimulatory molecules (CD40, CD80, and CD86) and major histocompatibility complex 2 and enhance secretion of IL-10, leading to induction of Tregs. ${ }^{97,98}$ VDR expression exhibited a maturation stage-specific pattern with greatest expression on human naive and memory $\mathrm{T}$ cells. ${ }^{25} \mathrm{We}$ are not aware of a research study demonstrating the expression of VDR on Tregs, so it remains controversial whether the actions of vitamin $\mathrm{D}_{3}$ on this cell population are via a direct and/or indirect manner. Regardless, accumulating evidence supports the notion that vitamin D could prevent autoimmune diseases, allograft rejection, and GVHD by expanding Tregs and inhibiting Th17 cells. ${ }^{26,99}$ A positive correlation was identified between vitamin $\mathrm{D}$ status and $\mathrm{CD} 4{ }^{+} \mathrm{FOXP} 3^{+}$Tregs in the serum and the airways of patients with moderate to severe asthma. ${ }^{100}$ Moreover, four of five trials in patients with autoimmune diseases, including T1D, MS, and Addison disease, reported vitamin $\mathrm{D}_{3}$ supplementation (dose range: 2000, 4000, 7000, or 14,000 IU/ $\mathrm{d}$ for $>3$ months) increased circulating Treg levels and suppressive function. ${ }^{101}$ In patients with ulcerative colitis, ex vivo treatment of $\mathrm{T}$ cells with VDR agonists augmented the expression of this receptor in Th2 cells and further promoted their conversion to Tregs (iTregs), upregulating TGF- $\beta$ mRNA levels. ${ }^{102}$ In mouse models for autoimmune diseases, such as RA and T1D, vitamin $\mathrm{D}_{3}$ was also observed to prevent disease by elevating Treg levels. ${ }^{103,104}$ In healthy individuals, administration of a high dose of vitamin $\mathrm{D}_{3}$ (140,000 IU per month for 3 months) enhanced Treg frequency accompanied by a significant correlation with increasing $25(\mathrm{OH}) \mathrm{D}_{3}$ serum levels. ${ }^{105,106}$ When activated human $\mathrm{T}$ cells from healthy individuals in culture are examined, treatment with $1 \alpha, 25(\mathrm{OH})_{2} \mathrm{D}_{3}$ promoted iTreg development with significant upregulation of CTLA-4 and FOXP3 expression; the latter required IL-2 in the culture. ${ }^{94}$ Furthermore, $1 \alpha, 25(\mathrm{OH})_{2} \mathrm{D}_{3}$ enhanced the selective expansion of $\mathrm{FOXP}^{+}$Tregs over conventional T cells (FOXP3 ${ }^{-}$) in vitro, and the former population had increased key Treg molecules (ie, CTLA-4, PD-1, and CD25), suppressive function, and a migratory signature specific for homing to sites of inflammation. ${ }^{107,108}$ Importantly, these results were also detected using ex vivo T cells from patients with autoimmune diseases, including T1D and MS. ${ }^{27,109}$

Although further research is needed to clarify the potential benefits of vitamin D supplementation, its long-term use may influence the Treg compartment indirectly through antigen-presenting cells and/or directly via VDR signals in $\mathrm{CD} 4{ }^{+} \mathrm{FOXP}^{+}{ }^{+} \mathrm{T}$ cells. Accordingly, VDREs were found in a conserved noncoding sequence region of the human FOXP3 gene, and in response to $1 \alpha, 25(\mathrm{OH})_{2} \mathrm{D}_{3}$, such VDREs augmented the FOXP3 promotor activity. Therefore, through direct VDR binding to the FOXP3 gene, $1 \alpha, 25(\mathrm{OH})_{2} \mathrm{D}_{3}$ may affect human immune responses by regulating FOXP3 expression. ${ }^{110}$ Although many individuals take vitamin $\mathrm{D}$ to support bone health, if elevation of Treg levels occurs in this population, it could result in an off-target benefit by preventing or diminishing inflammatory associated disease or alternatively could have a negative effect on cancer development/progression.

\section{TNF Inhibitor Family: Modulation of the Immune System to Control Inflammation and Unintentional Regulation of the Patient's Treg Compartment}

TNF antagonists are medications that are not being prescribed with the intent to augment the patient's Treg compartment to treat inflammatory diseases. These inhibitors, which block signaling via TNF receptors (TNFRs) 1 and 2, are currently being used to treat millions of patients for such diseases. TNFR2 reduces the severity of arthritis in preclinical animal studies, and it is important in the maintenance of Treg stability and function. ${ }^{11}$ Since 1998, five anti-TNF- $\alpha$ compounds have received FDA approval (Table $2^{112}$ ) and are clinically available to treat an increasing number of autoimmune inflammatory disorders. These drugs, which include monoclonal antibodies and a fusion protein, effectively impede TNFR signaling via binding to the TNF- $\alpha$ ligand. An estimated $7 \%$ to $10 \%$ of 
the world's population is affected by autoimmune diseases. ${ }^{113}$ Chronic inflammation and many disease symptoms in RA, ulcerative colitis, Crohn disease, psoriasis, psoriatic arthritis, ankylosing spondylitis, and juvenile idiopathic arthritis have been diminished in patients after biologic TNF- $\alpha$ inhibitors have been used for treatment. ${ }^{7,28,114}$ Currently, the underlying cause of these beneficial effects remains to be understood, but it has been assumed to be reduced Th1/Tc1 inflammation by direct inhibition of TNF signaling in these $\mathrm{T}$ cells.

TNF- $\alpha$ is the first cytokine to appear in the blood after injury or stress and is typically overproduced in many autoimmune diseases. ${ }^{7,28,114}$ Two TNFRs can bind and signal via nonoverlapping pathways. TNFR1 (p55) and TNFR2 (p75), although structurally related, mediate different biological function after binding of TNF- $\alpha .^{29}$ Notably, in contrast to TNFR1, which is ubiquitously expressed, TNFR2 is limited to lymphocyte populations. This receptor is reportedly activated more effectively by transmembrane TNF compared with the soluble form. ${ }^{115}$ TNFR1 contains a death domain and, as the primary signaling receptor on most cell types, is responsible for most of the proinflammatory, cytotoxic, and apoptotic effects typically attributed to TNF. ${ }^{115}$ In contrast, TNFR2 lacks a death domain but is principally responsible for signals that promote lymphocyte activation and proliferation via NF- $\mathrm{B}$, activator protein 1 , and the mitogenactivated protein kinase pathways. ${ }^{115-117}$ Interestingly, TNF family members, including TNFR2, expressed on Treg progenitors in the thymus contribute to signals that drive their differentiation. ${ }^{118}$ Notably, in the context of the present review, TNFR2 can provide co-stimulatory function in mature $\mathrm{T}$ cells and augment responses to antigen-driven T-cell receptor signaling. ${ }^{30,119}$ More specifically, TNFR2 is predominantly expressed by a subset of human and mouse $\mathrm{CD} 4{ }^{+} \mathrm{CD} 25^{+} \mathrm{FOXP} 3^{+}$Tregs, estimated to be approximately $30 \%$ to $40 \%$ of activated memory populations, but not naive Tregs, which reportedly lack TNFR2 expression. ${ }^{120}$ TNFR2 expression on Tregs is associated with functional ability, and several experimental studies have found that activation of TNFR2 can augment host Treg cell expansion and protect against acute GVHD. ${ }^{30,119,121,122}$

Although controlling symptoms and ameliorating disease evidence a pathogenic role for TNF- $\alpha$ in multiple autoimmune and inflammatory disorders, up to $40 \%$ of individuals do not respond to anti-TNF treatment, and disease augmentation has also been observed. ${ }^{7,123}$ The explanation for such diverse outcomes likely resides in different signaling pathways associated with various diseases together with how an individual's immune system responds, including which cell types and the biological reagent prescribed. For example, in studies of patients with RA, the TNFR2 fusion protein etanercept did not affect Tregs, whereas patients treated with adalimumab or infliximab exhibited increased numbers and functions by these cells. ${ }^{112,124,125}$ In addition, it is likely that the timing of treatment and period of exposure to the biologicals are important, as Bystrom et $\mathrm{al}^{7}$ reported in RA; although TNF- $\alpha$ can enhance T-cell responses, sustained exposure renders them hyporesponsive, so TNF blockers may have different effects administered early in disease.

Multiple cell populations can be modulated in patients after even brief TNF inhibitor exposure. Some populations of Tregs and Th17 cells derive from similar progenitors, and Tregs can promote differentiation of Th17 cells, whereas Th17 can promote expansion of Tregs. ${ }^{126}$ It may therefore not be surprising that interfering with TNF signaling affects both regulatory and effector T-cell populations. A number of studies support the notion that TNF inhibitor treatment of patients with RA affects Treg numbers and function and that these Treg outcomes are associated with improvement in RA symptoms. ${ }^{31,124,127,128}$ However, in one RA study, patients receiving adalimumab exhibited a decrease in Th 1 cells, Th17 cells, and IFN- $\gamma$ producing $\mathrm{CD} 8^{+} \mathrm{T}$ cells and an increase in the proportion of Tregs, but differences in Treg levels were not found between patients responding or not responding to therapy. ${ }^{125}$ The authors speculated that an increase in IFN- $\gamma$ production caused by recovery of natural killer cell function, together with expanded Tregs, contributed to decreasing the Th17 response in anti$\mathrm{TNF}$-treated patients with RA. Thus, in this study, blocking TNF and likely further lowering free TNF levels because of ameliorating disease led to an increased proportion of Tregs. These results may represent compensatory effects that result from control of the patient's immune system by the TNF antagonists.

Before treatment, despite elevated levels of circulating TNF- $\alpha$, both diminished and no change in Treg levels have been reported in patients with ankylosing spondylitis versus healthy controls. ${ }^{32,129}$ In a fairly large study, patients with ankylosing spondylitis $(>200)$ treated for 6 months with etanercept, adalimumab, or intravenous infliximab resulted in approximately $75 \%$ of clinical responders with significantly decreased levels of Th17 and increased levels of circulating Treg cells, whereas nonresponders whose disease was not diminished failed to have these changes. ${ }^{32}$ Significantly, lower frequencies of Tregs found in both responders and nonresponders compared with healthy controls support the notion that this compartment is important in disease outcome. Treg manipulation, although unintentional in this study, warrants more direct and specific targeting to further improve AS treatment. ${ }^{32}$ Moreover, it is apparent that elevation of TNF levels in some autoimmune patients may not translate to higher levels of Tregs, a result that is not surprising in that multiple cytokines are dysregulated and thus multiple signals are likely involved in determining the outcome on Treg cell counts and function. Results regarding Tregs have also varied in patients with psoriasis. In one study $(n=21)$, adalimumab decreased Th17, Th1, and other effector cells, and the number of $\mathrm{CD}^{+}{ }^{+} \mathrm{CD} 25^{+} \mathrm{FOXP}^{+}$cells increased in the peripheral blood. ${ }^{130}$ The Treg increase was associated with a good clinical response (reduction in the psoriasis area severity index). Nonetheless, some patients had decreased numbers of Tregs, although this decrease was associated with 
aggravation of disease. ${ }^{130}$ In a recent study $(n=32)$ of patients severely affected with psoriasis 1 week after a single pulse treatment with adalimumab, Tregs from peripheral blood exhibited decreased anti-CD3 and anti-CD28 ex vivo stimulation and diminished cytokine (eg, IL-10) production. ${ }^{131}$ The authors also conclude that the number of Treg cells was reduced after pulse therapy; however, it is not known whether such results would have been maintained after continued treatment and longer periods after therapy. ${ }^{131}$

Recently, the risk of ulcerative colitis in a Chinese population was proposed to be associated with single-nucleotide polymorphisms in the human FOXP3 locus, which could be associated with diminished numbers or function. ${ }^{132}$ Studies have found lower levels of Treg cells in the lamina propria in IBD and increased apoptosis of these cells. ${ }^{133,134}$ Infliximab treatment of patients with active IBD diminished Treg apoptosis. ${ }^{134}$ Several studies of patients with IBD also reported increases in peripheral Treg cells after anti-TNF- $\alpha$ treatment. Guidi et al ${ }^{135}$ reported elevation in blood but not the lamina propria of patients $(n=32)$ after several weeks of infliximab, certolizumab, or adalimumab treatment. A recent study with a small number of patients with $\mathrm{CD}$ $(n=8)$ reported diminished disease index scores after a single treatment with adalimumab or infliximab treatment, which was associated with increased CD127- Treg levels. ${ }^{136}$

In total, use of TNF- $\alpha$ biological blocking agents in a number of autoimmune and inflammatory disorders clearly via direct and/or indirect signaling affected the patients' Treg cell compartment. Reported effects have been observed after both single and more prolonged treatment protocols, and both increases and decreases in Tregs have been identified. It may be worthwhile to consider that because TNF inhibitors promote demargination, such changes in their trafficking could differentially alter the levels of Tregs in the peripheral blood and tissue compartments. Currently, it remains unclear whether TNF stimulates or inhibits functional Treg suppression. In addition, whether such Treg compartment changes may alter not only the disease extant but also other responses in the patient remains to be understood.

\section{Conclusion}

$\mathrm{CD} 4{ }^{+} \mathrm{CD} 25^{+} \mathrm{FOXP} 3{ }^{+} \mathrm{CD} 127^{\text {lo }}$ Treg cells are nonredundant mediators of immune tolerance, critical to prevent autoimmune disease and promote an anti-inflammatory tissue environment. A number of frequently prescribed medications, including estrogen, metformin, statins, vitamin $\mathrm{D}$, and TNF blockers, can unintentionally alter the Treg compartment in patients. Other unidentified drugs may also affect patient Treg cells. For example, aspirin, a broadly used nonsteroidal anti-inflammatory drug to treat pain and inflammation, possesses antithrombotic properties. Lowdose daily aspirin is commonly prescribed in patients who have cardiovascular disease or who have already had a myocardial infarction or stroke to decrease the risk of recurrence and other blood flow problems. ${ }^{137}$ Preclinical studies have found that aspirin treatment can augment Treg numbers and their development in animal models of inflammatory disease, such as MS; however, nonsteroidal anti-inflammatory drug alterations of Tregs in humans await clinical evaluation. ${ }^{138}$ Clearly, inflammation may underlie and/or complicate nearly each of the chronic conditions discussed in the present review. It is therefore important to note that inflammation can directly and/or indirectly regulate Tregs via affecting infiltrating and parenchymal cell populations. Chemokines, cytokines, prostaglandins, and eicosanoids produced by monocytes and epithelial cells can have a multitude of effects on Tregs, including affecting their stability, trafficking, and function. One pathway through which inflammatory environments could affect Treg cells is via stability of FOXP3 expression after epigenetic modifications (ie, as a consequence of the methylation of the FOXP3 locus). For example, the proinflammatory cytokine IL-6 contributes to the methylation of this gene via the methyltransferase Dnmt3a, leading to the loss of Foxp3 in inflamed tissues. ${ }^{139,140}$ Within the context of this review, it is interesting that signaling through TNFR2 was recently demonstrated to inhibit DNA methylation at the FOXP3 promoter, thereby maintaining the expression of this master transcription factor in Tregs. ${ }^{111}$

Varying and sometimes opposing effects on the Treg compartment have been observed using the same medication. The length of treatment, dosing regimen, and patient age, ethnicity, and sex may account for such findings. In addition, the specific disorder, the tissue compartment, and the stage of disease likely affect the differentiated state of the Treg populations and therefore the specific signaling pathways affected by the medication administered. Enhancing the Treg compartment can skew the patient's immune system toward an antiinflammatory phenotype, which, dependent on the condition being treated, could provide unanticipated benefit. In some circumstances, for example, patients with cancerous or precancerous conditions, such effects might theoretically promote tumor development or progression, but this requires further study. Currently, it is accurate to state that multiple medications prescribed to large numbers of patients influence the Treg compartment; however, it remains to be understood how such effects affect their disease outcome and long-term health.

\section{Acknowledgments}

We thank our laboratory colleagues for cientific discussions and Dr. Christopher Kanakry (NIH/National Cancer Institute) for critically reviewing the manuscript.

\section{References}

1. Sakaguchi S, Sakaguchi N, Asano M, Itoh M, Toda M: Immunologic self-tolerance maintained by activated $T$ cells expressing IL-2 
receptor alpha-chains (CD25): breakdown of a single mechanism of self-tolerance causes various autoimmune diseases. J Immunol 1995, 155:1151-1164

2. Suri-Payer E, Amar AZ, Thornton AM, Shevach EM: CD $4^{+} \mathrm{CD} 25^{+} \mathrm{T}$ cells inhibit both the induction and effector function of autoreactive $\mathrm{T}$ cells and represent a unique lineage of immunoregulatory cells. J Immunol 1998, 160:1212-1218

3. Malek TR, Yu A, Vincek V, Scibelli P, Kong L: CD4 regulatory T cells prevent lethal autoimmunity in IL-2Rbeta-deficient mice. Implications for the nonredundant function of IL-2. Immunity 2002, 17:167-178

4. Williams LM, Rudensky AY: Maintenance of the Foxp3-dependent developmental program in mature regulatory $\mathrm{T}$ cells requires continued expression of Foxp3. Nat Immunol 2007, 8:277-284

5. Bennett CL, Brunkow ME, Ramsdell F, O'Briant KC, Zhu Q, Fuleihan RL, Shigeoka AO, Ochs HD, Chance PF: A rare polyadenylation signal mutation of the FOXP3 gene (AAUAAA$>$ AAUGAA) leads to the IPEX syndrome. Immunogenetics 2001, $53: 435-439$

6. Dominguez-Villar M, Hafler DA: Regulatory T cells in autoimmune disease. Nat Immunol 2018, 19:665-673

7. Bystrom J, Clanchy FI, Taher TE, Mangat P, Jawad AS, Williams RO, Mageed RA: TNFalpha in the regulation of Treg and Th17 cells in rheumatoid arthritis and other autoimmune inflammatory diseases. Cytokine 2018, 101:4-13

8. Hartemann A, Bensimon G, Payan CA, Jacqueminet S, Bourron O, Nicolas N, Fonfrede M, Rosenzwajg M, Bernard C, Klatzmann D: Low-dose interleukin 2 in patients with type 1 diabetes: a phase $1 / 2$ randomised, double-blind, placebo-controlled trial. Lancet Diabetes Endocrinol 2013, 1:295-305

9. Koreth J, Matsuoka K, Kim HT, McDonough SM, Bindra B, Alyea EP 3rd, Armand P, Cutler C, Ho VT, Treister NS, Bienfang DC, Prasad S, Tzachanis D, Joyce RM, Avigan DE, Antin JH, Ritz J, Soiffer RJ: Interleukin-2 and regulatory T cells in graft-versus-host disease. N Engl J Med 2011, 365:2055-2066

10. Mao R, Xiao W, Liu H, Chen B, Yi B, Kraj P, She JX: Systematic evaluation of 640 FDA drugs for their effect on CD4(+)Foxp3(+) regulatory $\mathrm{T}$ cells using a novel cell-based high throughput screening assay. Biochem Pharmacol 2013, 85:1513-1524

11. Stuenkel CA, Davis SR, Gompel A, Lumsden MA, Murad MH, Pinkerton JV, Santen RJ: Treatment of symptoms of the menopause: an Endocrine Society Clinical Practice Guideline. J Clin Endocrinol Metab 2015, 100:3975-4011

12. Arruvito L, Sanz M, Banham AH, Fainboim L: Expansion of $\mathrm{CD} 4{ }^{+} \mathrm{CD} 25^{+}$and $\mathrm{FOXP}^{+}$regulatory $\mathrm{T}$ cells during the follicular phase of the menstrual cycle: implications for human reproduction. $\mathrm{J}$ Immunol 2007, 178:2572-2578

13. Adurthi S, Kumar MM, Vinodkumar HS, Mukherjee G, Krishnamurthy H, Acharya KK, Bafna UD, Uma DK, Abhishekh B, Krishna S, Parchure A, Alka M, Jayshree RS: Oestrogen Receptoralpha binds the FOXP3 promoter and modulates regulatory T-cell function in human cervical cancer. Sci Rep 2017, 7:17289

14. Rena G, Hardie DG, Pearson ER: The mechanisms of action of metformin. Diabetologia 2017, 60:1577-1585

15. Lee SY, Lee SH, Yang EJ, Kim EK, Kim JK, Shin DY, Cho ML: Metformin ameliorates inflammatory bowel disease by suppression of the STAT3 signaling pathway and regulation of the between Th17/Treg balance. PLoS One 2015, 10:e135858

16. Lee SY, Moon SJ, Kim EK, Seo HB, Yang EJ, Son HJ, Kim JK, Min JK, Park SH, Cho ML: Metformin suppresses systemic autoimmunity in Roquin(san/san) mice through inhibiting B cell differentiation into plasma cells via regulation of AMPK/mTOR/STAT3. J Immunol 2017, 198:2661-2670

17. Gualdoni GA, Mayer KA, Goschl L, Boucheron N, Ellmeier W, Zlabinger GJ: The AMP analog AICAR modulates the Treg/Th17 axis through enhancement of fatty acid oxidation. FASEB J 2016, 30: 3800-3809
18. Vaughan CJ, Gotto AM Jr, Basson CT: The evolving role of statins in the management of atherosclerosis. J Am Coll Cardiol 2000, 35:1-10

19. Forero-Pena DA, Gutierrez FR: Statins as modulators of regulatory Tcell biology. Mediators Inflamm 2013, 2013:167086

20. Wang ZX, Wang CQ, Li XY, Ding Y, Feng GK, Jiang XJ: Changes of naturally occurring $\mathrm{CD} 4(+) \mathrm{CD} 25(+)$ FOXP3(+) regulatory $\mathrm{T}$ cells in patients with acute coronary syndrome and the beneficial effects of atorvastatin treatment. Int Heart J 2015, 56:163-169

21. Zhang D, Wang S, Guan Y, Wang L, Xie W, Li N, Zhao P, Su G: Effect of oral atorvastatin on $\mathrm{CD} 4{ }^{+} \mathrm{CD} 25^{+}$regulatory $\mathrm{T}$ cells, FoxP3 expression, and prognosis in patients with ST-segment elevated myocardial infarction before primary percutaneous coronary intervention. J Cardiovasc Pharmacol 2011, 57:536-541

22. Rosen CJ: Clinical practice. Vitamin D insufficiency. N Engl J Med 2011, 364:248-254

23. Kongsbak M, Levring TB, Geisler C, von Essen MR: The vitamin d receptor and T cell function. Front Immunol 2013, 4:148

24. Benrashid M, Moyers K, Mohty M, Savani BN: Vitamin D deficiency, autoimmunity, and graft-versus-host-disease risk: implication for preventive therapy. Exp Hematol 2012, 40:263-267

25. Joseph RW, Bayraktar UD, Kim TK, St John LS, Popat U, Khalili J, Molldrem JJ, Wieder ED, Komanduri KV: Vitamin D receptor upregulation in alloreactive human T cells. Hum Immunol 2012, 73 : 693-698

26. Aly MG, Trojan K, Weimer R, Morath C, Opelz G, Tohamy MA, Daniel V: Low-dose oral cholecalciferol is associated with higher numbers of Helios $(+)$ and total Tregs than oral calcitriol in renal allograft recipients: an observational study. BMC Pharmacol Toxicol 2016, 17:24

27. Van Belle TL, Vanherwegen AS, Feyaerts D, De Clercq P, Verstuyf A, Korf H, Gysemans C, Mathieu C: 1,25Dihydroxyvitamin D3 and its analog TX527 promote a stable regulatory $\mathrm{T}$ cell phenotype in T cells from type 1 diabetes patients. PLoS One 2014, 9:e109194

28. Kalliolias GD, Ivashkiv LB: TNF biology, pathogenic mechanisms and emerging therapeutic strategies. Nat Rev Rheumatol 2016, 12 : 49-62

29. Vandenabeele P, Declercq W, Beyaert R, Fiers W: Two tumour necrosis factor receptors: structure and function. Trends Cell Biol 1995, 5:392-399

30. Chen X, Baumel M, Mannel DN, Howard OM, Oppenheim JJ: Interaction of TNF with TNF receptor type 2 promotes expansion and function of mouse CD4+CD25+ T regulatory cells. J Immunol 2007, 179:154-161

31. Nguyen DX, Ehrenstein MR: Anti-TNF drives regulatory $\mathrm{T}$ cell expansion by paradoxically promoting membrane TNF-TNF-RII binding in rheumatoid arthritis. J Exp Med 2016, 213:1241-1253

32. Xueyi L, Lina C, Zhenbiao W, Qing H, Qiang L, Zhu P: Levels of circulating Th17 cells and regulatory T cells in ankylosing spondylitis patients with an inadequate response to anti-TNF-alpha therapy. J Clin Immunol 2013, 33:151-161

33. Moulton VR: Sex hormones in acquired immunity and autoimmune disease. Front Immunol 2018, 9:2279

34. Weitzmann MN, Pacifici R: Estrogen deficiency and bone loss: an inflammatory tale. J Clin Invest 2006, 116:1186-1194

35. D’Amelio P, Grimaldi A, Di Bella S, Brianza SZM, Cristofaro MA, Tamone C, Giribaldi G, Ulliers D, Pescarmona GP, Isaia G: Estrogen deficiency increases osteoclastogenesis up-regulating $\mathrm{T}$ cells activity: a key mechanism in osteoporosis. Bone 2008, 43:92-100

36. Prieto GA, Rosenstein Y: Oestradiol potentiates the suppressive function of human $\mathrm{CD} 4 \mathrm{CD} 25$ regulatory $\mathrm{T}$ cells by promoting their proliferation. Immunology 2006, 118:58-65

37. Luo CY, Wang L, Sun C, Li DJ: Estrogen enhances the functions of CD4(+)CD25(+)Foxp3(+) regulatory T cells that suppress osteoclast differentiation and bone resorption in vitro. Cell Mol Immunol 2011, 8:50-58 
38. Khan D, Ansar Ahmed S: The immune system is a natural target for estrogen action: opposing effects of estrogen in two prototypical autoimmune diseases. Front Immunol 2015, 6:635

39. Polanczyk MJ, Carson BD, Subramanian S, Afentoulis M, Vandenbark AA, Ziegler SF, Offner H: Cutting edge: estrogen drives expansion of the $\mathrm{CD} 4{ }^{+} \mathrm{CD} 25^{+}$regulatory $\mathrm{T}$ cell compartment. J Immunol 2004, 173:2227-2230

40. Phiel KL, Henderson RA, Adelman SJ, Elloso MM: Differential estrogen receptor gene expression in human peripheral blood mononuclear cell populations. Immunol Lett 2005, 97:107-113

41. Polanczyk MJ, Hopke C, Vandenbark AA, Offner H: Treg suppressive activity involves estrogen-dependent expression of programmed death-1 (PD-1). Int Immunol 2007, 19:337-343

42. Aristimuno C, Teijeiro R, Valor L, Alonso B, Tejera-Alhambra M, de Andres C, Minarro DO, Lopez-Lazareno N, Faure F, Sanchez-Ramon S: Sex-hormone receptors pattern on regulatory T-cells: clinical implications for multiple sclerosis. Clin Exp Med 2012, 12:247-255

43. Mohammad I, Starskaia I, Nagy T, Guo J, Yatkin E, Vaananen K, Watford WT, Chen Z: Estrogen receptor alpha contributes to T cellmediated autoimmune inflammation by promoting $\mathrm{T}$ cell activation and proliferation. Sci Signal 2018, 11:eaap9415

44. Godet PG, May GR, Sutherland LR: Meta-analysis of the role of oral contraceptive agents in inflammatory bowel disease. Gut 1995, 37: $668-673$

45. Kane SV, Reddy D: Hormonal replacement therapy after menopause is protective of disease activity in women with inflammatory bowel disease. Am J Gastroenterol 2008, 103:1193-1196

46. Lee JH, Ulrich B, Cho J, Park J, Kim CH: Progesterone promotes differentiation of human cord blood fetal $\mathrm{T}$ cells into $\mathrm{T}$ regulatory cells but suppresses their differentiation into Th17 cells. J Immunol 2011, 187:1778-1787

47. Mao G, Wang J, Kang Y, Tai P, Wen J, Zou Q, Li G, Ouyang H, Xia G, Wang B: Progesterone increases systemic and local uterine proportions of $\mathrm{CD} 4{ }^{+} \mathrm{CD} 25^{+}$Treg cells during midterm pregnancy in mice. Endocrinology 2010, 151:5477-5488

48. Walecki M, Eisel F, Klug J, Baal N, Paradowska-Dogan A, Wahle E, Hackstein H, Meinhardt A, Fijak M: Androgen receptor modulates Foxp3 expression in $\mathrm{CD}^{+}{ }^{+} \mathrm{CD} 25^{+} \mathrm{Foxp}^{+}$regulatory T-cells. Mol Biol Cell 2015, 26:2845-2857

49. Calle MC, Fernandez ML: Inflammation and type 2 diabetes. Diabetes Metab 2012, 38:183-191

50. Feuerer M, Herrero L, Cipolletta D, Naaz A, Wong J, Nayer A, Lee J, Goldfine AB, Benoist C, Shoelson S, Mathis D: Lean, but not obese, fat is enriched for a unique population of regulatory $\mathrm{T}$ cells that affect metabolic parameters. Nat Med 2009, 15:930-939

51. Li C, Spallanzani RG, Mathis D: Visceral adipose tissue Tregs and the cells that nurture them. Immunol Rev 2020, 295:114-125

52. Ilan Y, Maron R, Tukpah AM, Maioli TU, Murugaiyan G, Yang K, Wu HY, Weiner HL: Induction of regulatory $\mathrm{T}$ cells decreases adipose inflammation and alleviates insulin resistance in ob/ob mice. Proc Natl Acad Sci U S A 2010, 107:9765-9770

53. Winer S, Chan Y, Paltser G, Truong D, Tsui H, Bahrami J, Dorfman R, Wang Y, Zielenski J, Mastronardi F, Maezawa Y, Drucker DJ, Engleman E, Winer D, Dosch HM: Normalization of obesity-associated insulin resistance through immunotherapy. Nat Med 2009, 15:921-929

54. Sheikh V, Zamani A, Mahabadi-Ashtiyani E, Tarokhian H, Borzouei S, Alahgholi-Hajibehzad M: Decreased regulatory function of CD4(+)CD25(+)CD45RA(+) T cells and impaired IL-2 signalling pathway in patients with type 2 diabetes mellitus. Scand J Immunol 2018, 88:e12711

55. Laparra A, Tricot S, Le Van M, Damouche A, Gorwood J, Vaslin B, Favier B, Benoist S, Ho Tsong Fang R, Bosquet N, Le Grand R, Chapon C, Lambotte O, Bourgeois C: The frequencies of immunosuppressive cells in adipose tissue differ in human, non-human primate, and mouse models. Front Immunol 2019, 10:117
56. Kim K, Wang L, Hwang I: Acute inhibition of selected membraneproximal mouse $\mathrm{T}$ cell receptor signaling by mitochondrial antagonists. PLoS One 2009, 4:e7738

57. Solano ME, Sander V, Wald MR, Motta AB: Dehydroepiandrosterone and metformin regulate proliferation of murine $\mathrm{T}$ lymphocytes. Clin Exp Immunol 2008, 153:289-296

58. Son HJ, Lee J, Lee SY, Kim EK, Park MJ, Kim KW, Park SH, Cho ML: Metformin attenuates experimental autoimmune arthritis through reciprocal regulation of Th17/Treg balance and osteoclastogenesis. Mediators Inflamm 2014, 2014:973986

59. Sun Y, Tian T, Gao J, Liu X, Hou H, Cao R, Li B, Quan M, Guo L: Metformin ameliorates the development of experimental autoimmune encephalomyelitis by regulating $\mathrm{T}$ helper 17 and regulatory $\mathrm{T}$ cells in mice. J Neuroimmunol 2016, 292:58-67

60. Tang TT, Song Y, Ding YJ, Liao YH, Yu X, Du R, Xiao H, Yuan J, Zhou ZH, Liao MY, Yao R, Jevallee H, Shi GP, Cheng X: Atorvastatin upregulates regulatory $\mathrm{T}$ cells and reduces clinical disease activity in patients with rheumatoid arthritis. J Lipid Res 2011, 52: $1023-1032$

61. Kim YC, Kim KK, Shevach EM: Simvastatin induces Foxp3+ T regulatory cells by modulation of transforming growth factor-beta signal transduction. Immunology 2010, 130:484-493

62. Nath N, Khan M, Paintlia MK, Singh I, Hoda MN, Giri S: Metformin attenuated the autoimmune disease of the central nervous system in animal models of multiple sclerosis. J Immunol 2009, 182 $8005-8014$

63. Lee CF, Lo YC, Cheng $\mathrm{CH}$, Furtmuller GJ, Oh B, AndradeOliveira V, Thomas AG, Bowman CE, Slusher BS, Wolfgang MJ, Brandacher G, Powell JD: Preventing allograft rejection by targeting immune metabolism. Cell Rep 2015, 13:760-770

64. Negrotto L, Farez MF, Correale J: Immunologic effects of metformin and pioglitazone treatment on metabolic syndrome and multiple sclerosis. JAMA Neurol 2016, 73:520-528

65. Wang M, Chen F, Wang J, Zeng Z, Yang Q, Shao S: Th17 and Treg lymphocytes in obesity and Type 2 diabetic patients. Clin Immunol 2018, 197:77-85

66. Buhaescu I, Izzedine H: Mevalonate pathway: a review of clinical and therapeutical implications. Clin Biochem 2007, 40:575-584

67. Corsini A, Bellosta S, Baetta R, Fumagalli R, Paoletti R, Bernini F: New insights into the pharmacodynamic and pharmacokinetic properties of statins. Pharmacol Ther 1999, 84:413-428

68. Greenwood J, Steinman L, Zamvil SS: Statin therapy and autoimmune disease: from protein prenylation to immunomodulation. Nat Rev Immunol 2006, 6:358-370

69. Schachter M: Chemical, pharmacokinetic and pharmacodynamic properties of statins: an update. Fundam Clin Pharmacol 2005, 19 : $117-125$

70. Ward NC, Watts GF, Eckel RH: Statin toxicity. Circ Res 2019, 124: $328-350$

71. Marino F, Guasti L, Cosentino M, Rasini E, Ferrari M, Maio RC, Loraschi A, Cimpanelli MG, Schembri L, Legnaro M, Molteni E, Crespi C, Crema F, Venco A, Lecchini S: Simvastatin treatment in subjects at high cardiovascular risk modulates AT1R expression on circulating monocytes and T lymphocytes. J Hypertens 2008, 26: 1147-1155

72. Ghittoni R, Napolitani G, Benati D, Ulivieri C, Patrussi L, Laghi Pasini F, Lanzavecchia A, Baldari CT: Simvastatin inhibits the MHC class II pathway of antigen presentation by impairing Ras superfamily GTPases. Eur J Immunol 2006, 36:2885-2893

73. Kwak B, Mulhaupt F, Myit S, Mach F: Statins as a newly recognized type of immunomodulator. Nat Med 2000, 6:1399-1402

74. Xie W, Li P, Wang Z, Chen J, Lin Z, Liang X, Mo Y: Rosuvastatin may reduce the incidence of cardiovascular events in patients with acute coronary syndromes receiving percutaneous coronary intervention by suppressing miR-155/SHIP-1 signaling pathway. Cardiovasc Ther 2014, 32:276-282 
75. Sorathia N, Al-Rubaye H, Zal B: The effect of statins on the functionality of $\mathrm{CD}^{+}{ }^{+} \mathrm{CD} 25^{+} \mathrm{FOXP}^{+}$regulatory $\mathrm{T}$-cells in acute coronary syndrome: a systematic review and meta-analysis of randomised controlled trials in Asian populations. Eur Cardiol 2019, 14:123-129

76. Mausner-Fainberg K, Luboshits G, Mor A, Maysel-Auslender S, Rubinstein A, Keren G, George J: The effect of HMG-CoA reductase inhibitors on naturally occurring $\mathrm{CD} 4{ }^{+} \mathrm{CD} 25^{+} \mathrm{T}$ cells. Atherosclerosis 2008, 197:829-839

77. Mallat Z, Ait-Oufella H, Tedgui A: Regulatory T cell responses: potential role in the control of atherosclerosis. Curr Opin Lipidol 2005, 16:518-524

78. Meng X, Zhang K, Li J, Dong M, Yang J, An G, Qin W, Gao F, Zhang C, Zhang Y: Statins induce the accumulation of regulatory T cells in atherosclerotic plaque. Mol Med 2012, 18:598-605

79. Mira E, Leon B, Barber DF, Jimenez-Baranda S, Goya I, Almonacid L, Marquez G, Zaballos A, Martinez AC, Stein JV, Ardavin C, Manes S: Statins induce regulatory T cell recruitment via a CCL1 dependent pathway. J Immunol 2008, 181:3524-3534

80. Rodriguez-Perea AL, Rojas M, Velilla-Hernandez PA: High concentrations of atorvastatin reduce in-vitro function of conventional $\mathrm{T}$ and regulatory T cells. Clin Exp Immunol 2019, 196:237-248

81. Al-Husein BA, Dawah B, Bani-Hani S, Al Bashir SM, AlSawalmeh KM, Ayoub NM: Immunomodulatory effect of statins on Regulatory T Lymphocytes in human colorectal cancer is determined by the stage of disease. Oncotarget 2018, 9:35752-35761

82. Rodriguez-Perea AL, Montoya CJ, Olek S, Chougnet CA, Velilla PA: Statins increase the frequency of circulating CD4+ FOXP3+ regulatory $\mathrm{T}$ cells in healthy individuals. J Immunol Res 2015, 2015: 762506

83. Holick MF: Environmental factors that influence the cutaneous production of vitamin D. Am J Clin Nutr 1995, 61:638S-645S

84. Bikle DD, Vitamin D: Newer concepts of its metabolism and function at the basic and clinical level. J Endocr Soc 2020, 4:bvz038

85. Norman AW: Sunlight, season, skin pigmentation, vitamin D, and 25hydroxyvitamin D: integral components of the vitamin D endocrine system. Am J Clin Nutr 1998, 67:1108-1110

86. Adorini L, Penna G: Control of autoimmune diseases by the vitamin D endocrine system. Nat Clin Pract Rheumatol 2008, 4:404-412

87. Holick MF: Vitamin D deficiency. N Engl J Med 2007, 357:266-281

88. Manson JE, Brannon PM, Rosen CJ, Taylor CL: Vitamin D deficiency - is there really a pandemic? N Engl J Med 2016, 375: $1817-1820$

89. Rosen CJ, Abrams SA, Aloia JF, Brannon PM, Clinton SK, DurazoArvizu RA, Gallagher JC, Gallo RL, Jones G, Kovacs CS, Manson JE, Mayne ST, Ross AC, Shapses SA, Taylor CL: IOM committee members respond to Endocrine Society vitamin D guideline. J Clin Endocrinol Metab 2012, 97:1146-1152

90. Taylor CL, Rosen CJ, Dwyer JT: Considerations in dietetic counseling for vitamin D. J Acad Nutr Diet 2019, 119:901-909

91. Haussler MR, Jurutka PW, Mizwicki M, Norman AW: Vitamin D receptor (VDR)-mediated actions of 1alpha,25(OH)(2)vitamin $\mathrm{D}(3)$ : genomic and non-genomic mechanisms. Best Pract Res Clin Endocrinol Metab 2011, 25:543-559

92. Saccone D, Asani F, Bornman L: Regulation of the vitamin D receptor gene by environment, genetics and epigenetics. Gene 2015, 561:171-180

93. Bikle DD: Vitamin D metabolism, mechanism of action, and clinical applications. Chem Biol 2014, 21:319-329

94. Jeffery LE, Burke F, Mura M, Zheng Y, Qureshi OS, Hewison M, Walker LS, Lammas DA, Raza K, Sansom DM: 1,25-Dihydroxyvitamin D3 and IL-2 combine to inhibit T cell production of inflammatory cytokines and promote development of regulatory $\mathrm{T}$ cells expressing CTLA-4 and FoxP3. J Immunol 2009, 183:5458-5467

95. Baeke F, Korf H, Overbergh L, van Etten E, Verstuyf A, Gysemans C, Mathieu C: Human T lymphocytes are direct targets of 1,25-dihydroxyvitamin D3 in the immune system. J Steroid Biochem Mol Biol 2010, 121:221-227
96. Toubi E, Shoenfeld Y: The role of vitamin D in regulating immune responses. Isr Med Assoc J 2010, 12:174-175

97. Tokuda N, Mizuki N, Kasahara M, Levy RB: 1,25-Dihydroxyvitamin D3 down-regulation of HLA-DR on human peripheral blood monocytes. Immunology 1992, 75:349-354

98. Adorini L, Penna G: Dendritic cell tolerogenicity: a key mechanism in immunomodulation by vitamin D receptor agonists. Hum Immunol 2009, 70:345-352

99. Hayes CE, Hubler SL, Moore JR, Barta LE, Praska CE, Nashold FE: Vitamin D actions on CD4(+) T cells in autoimmune disease. Front Immunol 2015, 6:100

100. Chambers ES, Nanzer AM, Richards DF, Ryanna K, Freeman AT, Timms PM, Martineau AR, Griffiths CJ, Corrigan CJ, Hawrylowicz CM: Serum 25-dihydroxyvitamin D levels correlate with CD4(+)Foxp3(+) T-cell numbers in moderate/severe asthma. J Allergy Clin Immunol 2012, 130:542-544

101. Fisher SA, Rahimzadeh M, Brierley C, Gration B, Doree C, Kimber CE, Plaza Cajide A, Lamikanra AA, Roberts DJ: The role of vitamin $\mathrm{D}$ in increasing circulating $\mathrm{T}$ regulatory cell numbers and modulating $\mathrm{T}$ regulatory cell phenotypes in patients with inflammatory disease or in healthy volunteers: a systematic review. PLoS One 2019, 14:e0222313

102. Lu D, Lan B, Din Z, Chen H, Chen G: A vitamin D receptor agonist converts $\mathrm{CD}^{+} \mathrm{T}$ cells to Foxp $3^{+}$regulatory $\mathrm{T}$ cells in patients with ulcerative colitis. Oncotarget 2017, 8:53552-53562

103. Gregori S, Giarratana N, Smiroldo S, Uskokovic M, Adorini L: A 1alpha,25-dihydroxyvitamin $\mathrm{D}(3)$ analog enhances regulatory T-cells and arrests autoimmune diabetes in NOD mice. Diabetes 2002, 51: $1367-1374$

104. Zhou L, Wang J, Li J, Li T, Chen Y, June RR, Zheng SG: 1,25Dihydroxyvitamin D3 ameliorates collagen-induced arthritis via suppression of Th17 cells through miR-124 mediated inhibition of IL6 signaling. Front Immunol 2019, 10:178

105. Prietl B, Pilz S, Wolf M, Tomaschitz A, Obermayer-Pietsch B, Graninger W, Pieber TR: Vitamin D supplementation and regulatory $\mathrm{T}$ cells in apparently healthy subjects: vitamin $\mathrm{D}$ treatment for autoimmune diseases? Isr Med Assoc J 2010, 12:136-139

106. Prietl B, Treiber G, Mader JK, Hoeller E, Wolf M, Pilz S, Graninger WB, Obermayer-Pietsch BM, Pieber TR: High-dose cholecalciferol supplementation significantly increases peripheral CD4(+) Tregs in healthy adults without negatively affecting the frequency of other immune cells. Eur J Nutr 2014, 53:751-759

107. Urry Z, Chambers ES, Xystrakis E, Dimeloe S, Richards DF, Gabrysova L, Christensen J, Gupta A, Saglani S, Bush A, O'Garra A, Brown Z, Hawrylowicz CM: The role of 1alpha,25-dihydroxyvitamin D3 and cytokines in the promotion of distinct Foxp3 $3^{+}$and $\mathrm{IL}-10^{+}$ $\mathrm{CD}^{+}{ }^{+} \mathrm{T}$ cells. Eur J Immunol 2012, 42:2697-2708

108. Baeke F, Korf H, Overbergh L, Verstuyf A, Thorrez L, Van Lommel L, Waer M, Schuit F, Gysemans C, Mathieu C: The vitamin D analog, TX527, promotes a human $\mathrm{CD} 4{ }^{+} \mathrm{CD} 25$ highCD127low regulatory $\mathrm{T}$ cell profile and induces a migratory signature specific for homing to sites of inflammation. J Immunol 2011, 186:132-142

109. Correale J, Ysrraelit MC, Gaitan MI: Immunomodulatory effects of Vitamin D in multiple sclerosis. Brain 2009, 132:1146-1160

110. Kang SW, Kim SH, Lee N, Lee WW, Hwang KA, Shin MS, Lee SH, Kim WU, Kang I: 1,25-Dihyroxyvitamin D3 promotes FOXP3 expression via binding to vitamin D response elements in its conserved noncoding sequence region. J Immunol 2012, 188: $5276-5282$

111. Tseng WY, Huang YS, Clanchy F, McNamee K, Perocheau D, Ogbechi J, Luo SF, Feldmann M, McCann FE, Williams RO: TNF receptor 2 signaling prevents DNA methylation at the Foxp3 promoter and prevents pathogenic conversion of regulatory T cells. Proc Natl Acad Sci U S A 2019, 116:21666-21672

112. Kaymakcalan Z, Sakorafas P, Bose S, Scesney S, Xiong L, Hanzatian DK, Salfeld J, Sasso EH: Comparisons of affinities, avidities, and complement activation of adalimumab, infliximab, and 
etanercept in binding to soluble and membrane tumor necrosis factor. Clin Immunol 2009, 131:308-316

113. Cooper GS, Bynum ML, Somers EC: Recent insights in the epidemiology of autoimmune diseases: improved prevalence estimates and understanding of clustering of diseases. J Autoimmun 2009, 33: 197-207

114. Elliott MJ, Maini RN, Feldmann M, Long-Fox A, Charles P, Katsikis P, Brennan FM, Walker J, Bijl H, Ghrayeb J, Woody JN: Treatment of rheumatoid arthritis with chimeric monoclonal antibodies to tumor necrosis factor alpha. Arthritis Rheum 1993, 36: $1681-1690$

115. Grell M, Douni E, Wajant H, Lohden M, Clauss M, Maxeiner B, Georgopoulos S, Lesslauer W, Kollias G, Pfizenmaier K, Scheurich P: The transmembrane form of tumor necrosis factor is the prime activating ligand of the $80 \mathrm{kDa}$ tumor necrosis factor receptor. Cell 1995, 83:793-802

116. Arnett HA, Mason J, Marino M, Suzuki K, Matsushima GK, Ting JP: TNF alpha promotes proliferation of oligodendrocyte progenitors and remyelination. Nat Neurosci 2001, 4:1116-1122

117. Faustman D, Davis M: TNF receptor 2 pathway: drug target for autoimmune diseases. Nat Rev Drug Discov 2010, 9:482-493

118. Mahmud SA, Manlove LS, Schmitz HM, Xing Y, Wang Y, Owen DL, Schenkel JM, Boomer JS, Green JM, Yagita H, Chi H, Hogquist KA, Farrar MA: Costimulation via the tumor-necrosis factor receptor superfamily couples TCR signal strength to the thymic differentiation of regulatory T cells. Nat Immunol 2014, 15: 473-481

119. Chopra M, Biehl M, Steinfatt T, Brandl A, Kums J, Amich J, et al: Exogenous TNFR2 activation protects from acute GvHD via host T reg cell expansion. J Exp Med 2016, 213:1881-1900

120. Chen X, Subleski JJ, Kopf H, Howard OM, Mannel DN, Oppenheim JJ: Cutting edge: expression of TNFR2 defines a maximally suppressive subset of mouse $\mathrm{CD} 4^{+} \mathrm{CD} 25^{+} \mathrm{FoxP} 3^{+} \mathrm{T}$ regulatory cells: applicability to tumor-infiltrating T regulatory cells. J Immunol 2008, 180:6467-6471

121. Chen X, Subleski JJ, Hamano R, Howard OM, Wiltrout RH, Oppenheim JJ: Co-expression of TNFR2 and CD25 identifies more of the functional $\mathrm{CD} 4^{+} \mathrm{FOXP}^{+}$regulatory $\mathrm{T}$ cells in human peripheral blood. Eur J Immunol 2010, 40:1099-1106

122. Leclerc M, Naserian S, Pilon C, Thiolat A, Martin GH, Pouchy C, Dominique C, Belkacemi Y, Charlotte F, Maury S, Salomon BL, Cohen JL: Control of GVHD by regulatory T cells depends on TNF produced by $\mathrm{T}$ cells and TNFR2 expressed by regulatory $\mathrm{T}$ cells. Blood 2016, 128:1651-1659

123. Roda G, Jharap B, Neeraj N, Colombel JF: Loss of response to antiTNFs: definition, epidemiology, and management. Clin Transl Gastroenterol 2016, 7:e135

124. Nadkarni S, Mauri C, Ehrenstein MR: Anti-TNF-alpha therapy induces a distinct regulatory $\mathrm{T}$ cell population in patients with rheumatoid arthritis via TGF-beta. J Exp Med 2007, 204:33-39

125. Aravena O, Pesce B, Soto L, Orrego N, Sabugo F, Wurmann P, Molina MC, Alfaro J, Cuchacovich M, Aguillon JC, Catalan D: AntiTNF therapy in patients with rheumatoid arthritis decreases Th1 and Th17 cell populations and expands IFN-gamma-producing NK cell and regulatory $\mathrm{T}$ cell subsets. Immunobiology 2011, 216:1256-1263

126. Bettelli E, Carrier Y, Gao W, Korn T, Strom TB, Oukka M, Weiner HL, Kuchroo VK: Reciprocal developmental pathways for the generation of pathogenic effector $\mathrm{TH} 17$ and regulatory $\mathrm{T}$ cells. Nature 2006, 441:235-238

127. McGovern JL, Nguyen DX, Notley CA, Mauri C, Isenberg DA, Ehrenstein MR: Th17 cells are restrained by Treg cells via the inhibition of interleukin- 6 in patients with rheumatoid arthritis responding to anti-tumor necrosis factor antibody therapy. Arthritis Rheum 2012, 64:3129-3138

128. Nie H, Zheng Y, Li R, Guo TB, He D, Fang L, Liu X, Xiao L, Chen X, Wan B, Chin YE, Zhang JZ: Phosphorylation of FOXP3 controls regulatory $\mathrm{T}$ cell function and is inhibited by TNF-alpha in rheumatoid arthritis. Nat Med 2013, 19:322-328

129. Guo H, Zheng M, Zhang K, Yang F, Zhang X, Han Q, Chen ZN, Zhu P: Functional defects in CD4(+) CD25(high) FoxP3(+) regulatory cells in ankylosing spondylitis. Sci Rep 2016, 6:37559

130. Luan L, Han S, Wang H, Liu X: Down-regulation of the Th1, Th17, and Th22 pathways due to anti-TNF-alpha treatment in psoriasis. Int Immunopharmacol 2015, 29:278-284

131. Furiati SC, Catarino JS, Silva MV, Silva RF, Estevam RB, Teodoro RB, Pereira SL, Ataide M, Rodrigues V Jr, Rodrigues DBR: Th1, Th17, and Treg responses are differently modulated by TNF-alpha inhibitors and methotrexate in psoriasis patients. Sci Rep 2019, 9:7526

132. Xia SL, Ying SJ, Lin QR, Wang XQ, Hong WJ, Lin ZJ, Luo JK, Jiang Y: Association of ulcerative colitis with FOXP3 gene polymorphisms and its colonic expression in Chinese patients. Gastroenterol Res Pract 2019, 2019:4052168

133. Maul J, Loddenkemper C, Mundt P, Berg E, Giese T, Stallmach A, Zeitz M, Duchmann R: Peripheral and intestinal regulatory $\mathrm{CD}^{+}$ CD25(high) $\mathrm{T}$ cells in inflammatory bowel disease. Gastroenterology 2005, 128:1868-1878

134. Veltkamp C, Anstaett M, Wahl K, Moller S, Gangl S, Bachmann O, Hardtke-Wolenski M, Langer F, Stremmel W, Manns MP, SchulzeOsthoff K, Bantel $\mathrm{H}$ : Apoptosis of regulatory $\mathrm{T}$ lymphocytes is increased in chronic inflammatory bowel disease and reversed by anti-TNFalpha treatment. Gut 2011, 60:1345-1353

135. Guidi L, Felice C, Procoli A, Bonanno G, Martinelli E, Marzo M, Mocci G, Pugliese D, Andrisani G, Danese S, De Vitis I, Papa A, Armuzzi A, Rutella S: FOXP3(+) T regulatory cell modifications in inflammatory bowel disease patients treated with anti-TNFalpha agents. Biomed Res Int 2013, 2013:286368

136. Chiba T, Endo M, Miura S, Hayashi Y, Asakura Y, Oyama K, Matsumoto T: Regulatory T cells in Crohn's disease following antiTNF $\alpha$ therapy. J Gastroenterol Hepatol 2019, 4:378-381

137. Weiss HJ: The discovery of the antiplatelet effect of aspirin: a personal reminiscence. J Thromb Haemost 2003, 1:1869-1875

138. Mondal S, Jana M, Dasarathi S, Roy A, Pahan K: Aspirin ameliorates experimental autoimmune encephalomyelitis through interleukin-11mediated protection of regulatory T cells. Sci Signal 2018, 11:eaar8278

139. Floess S, Freyer J, Siewert C, Baron U, Olek S, Polansky J, Schlawe K, Chang HD, Bopp T, Schmitt E, Klein-Hessling S, Serfling E, Hamann A, Huehn J: Epigenetic control of the foxp3 locus in regulatory T cells. PLoS Biol 2007, 5:e38

140. Garg G, Muschaweckh A, Moreno H, Vasanthakumar A, Floess S, Lepennetier G, Oellinger R, Zhan Y, Regen T, Hiltensperger M, Peter C, Aly L, Knier B, Palam LR, Kapur R, Kaplan MH, Waisman A, Rad R, Schotta G, Huehn J, Kallies A, Korn T: Blimp1 prevents methylation of Foxp 3 and loss of regulatory $\mathrm{T}$ cell identity at sites of inflammation. Cell Rep 2019, 26:1854-1868.e5 